\title{
Model Discovery Learning Berbantuan Media Power Point Meningkatkan Hasil Belajar IPA Siswa SD
}

\author{
Ni. Kd. Aryantini ${ }^{1 *}$, I. W. Sujana ${ }^{2}$, I. G. A. Pt. Sri Darmawati ${ }^{3}$ \\ 1,2 Universitas Pendidikan Ganesha, Singaraja, Indonesia \\ ${ }^{3}$ Sekolah Dasar Negeri 1 Astina, Singaraja, Indonesia
}

\section{ARTICLE INFO}

\section{Article history:}

Received May 20, 2021

Revised May 26, 2021

Accepted June 26, 2021

Available online July 25, 2021

\section{Kata Kunci:}

Discovery Learning, PPT, Hasil

Belajar

Keywords:

Discovery Learning, PPT, Learning Outcomes

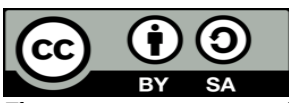

This is an open access article under the CC BY-SA license.

Copyright (C) 2021 by Author. Published by Universitas Pendidikan Ganesha.

\begin{abstract}
A B S T R A K
Kurangnya penggunaan media dan model pembelajaran yang inovatif menyebabkan rendahnya hasil belajar IPA. Oleh sebab itu diadakan penelitian tindakan kelas yang bertujuan untuk meningkatkan hasil belajar IPA siswa kelas V sekolah dasar melalui penerapan model discovery learning berbatuan media power point. Jenis penelitian ini adalah penelitian tindakan kelas yang ini terdiri dari 2 siklus dan masing-masing siklus terdiri dari tahap perencanaan, pelaksanaan, observasi, dan refleksi. Subjek peneitian ini adalah siswa kelas V sekolah dasar yang berjumlah 27 orang. Metode pengumpulan data yang digunakan dalam penelitian ini adalah metode tes. Instrumen penelitian yakni berupa tes pilihan ganda dengan 4 option. Teknik analisis data yakni analisis deskriptif kuantitatif yaitu; mencari mean, median, modus, daya serap, dan ketuntasan belajar siswa. Hasil penelitian tindakan kelas adalah model discovery learning berbantuan media power point dapat meningkatkan hasil belajar IPA siswa kelas V sekolah dasar yang diperoleh dari hasil peningkatan hasil belajar pada kegiatan pra siklus menuju siklus I terlihat cukup signifikan dengan perolehan peningkatan pada nilai rata-rata siswa sebesar 8,28 dan ketuntasan belajar sebesar 18,52\%. Sedangkan peningkatan hasil belajar siswa dari siklus I menuju siklus II terlihat signifikan karena perolehan peningkatan rata-rata nilai siswa sebesar 9,91 dan ketuntasan belajar sebesar 18,52\%. Berdasarkan hasil penelitian tindakan kelas diperoleh simpulan yakni terjadi peningkatan hasil belajar IPA melalui model discovery learning berbantuan media power point.
\end{abstract}

\begin{abstract}
A B S T R A C T
The lack of use of media and innovative learning models causes low science learning outcomes. Therefore, classroom action research was conducted which aims to improve science learning outcomes for fifth grade elementary school students through the application of a power point-based discovery learning model. This type of research is classroom action research which consists of 2 cycles and each cycle consists of planning, implementation, observation, and reflection stages. The subjects of this research are the fifth grade elementary school students, totaling 27 people. The data collection method used in this research is the test method. The research instrument is a multiple choice test with 4 options. The data analysis technique is quantitative descriptive analysis, namely; look for the mean, median, mode, absorption, and completeness of student learning. The results of classroom action research are discovery learning models assisted by power point media can improve science learning outcomes for fifth grade elementary school students obtained from the results of increasing learning outcomes in pre-cycle activities to cycle I looks quite significant with the acquisition of an increase in the average score of 8 students. .28 and learning completeness of $18.52 \%$. While the increase in student learning outcomes from cycle I to cycle II looks significant because the acquisition of an average increase in student scores is 9.91 and learning completeness is $18.52 \%$. Based on the results of classroom action research, it was concluded that there was an increase in science learning outcomes through discovery learning models assisted by power point media.
\end{abstract}

\section{PENDAHULUAN}

Pembelajaran IPA pada masa pandemi Covid-19 dilaksanakan dengan bantuan teknologi yang diharapkan dapat dilaksanakan dengan memberikan kegiatan penemuan sehingga dapat melaksanakan proses dan keterampilan IPA. "Ilmu yang memperlajari benda hidup dan benda mati adalah IPA" (Kumala, 2016). Ilmu yang menelaah keadaan alam, faktor-faktor yang memengaruhi, terjadi perubahanperubahan, hukum-hukum alam, dan bagi kehidupan terdapat manfaatnya adalah IPA. Muatan yang paling penting dilaksanakan di sekolah dasar adalah IPA karena memebrikan pengalaman belajar secara langsung agar siswa mampu paham terhadap alam sekitar dengan sikap ilmiah yang terdiri dari; metode kerja, metode berpikir dan metode memecahkan suatu permasalahan yang berkaitan dengan kehidupan 
sehari-hari (Dewi \& Negara, 2020; Abhyasari et al., 2020; Rianti \& Dibia, 2020). Siswa aktif dalam mengikuti proses kegiatan pembelajaran di kelas dan membuat siswa menemukan secara mandiri tentang materi yang mereka pelajari dengan memprioritaskan proses pembelajaran yang berpusat pada siswa dan guru hanya sebagai fasilitator dan diharapkan dapat menjadi wahana bagi siswa untuk mempelajari diri sendiri dan alam sekitar, serta prospek pengembangan lebih lanjut dalam menerapkannya di kehidupan sehari-hari, guru dan siswa secara bersama-sama mencapai tujuan pembelajaran yang diinginkan apabila pelaksanaan pembelajaran IPA terjadi secara efektif. Namun kenyataanya banyak kendala-kendala dalam kegiatan pembelajaran IPA (Phalguna \& Putra, 2020; Adnyana et al., 2019; Dewi et al., 2020).

Kegiatan pembelajaran IPA dapat ditunjang dengan media pembelajaran, alat yang membantu proses pembelajaran sehingga makna pesan dapat disampaikan dengan jelas dan efesien dan efektif adalah media pembelajaran (Nurrita, 2018). Memperoleh pesan dan informasi sehingga pemahaman materi lebih meningkat dan membentuk pengetahuan bagi siswa adalah fungsi media pembelajaran. Memberikan, mempermudah pembelajar agar lebih mengerti dan menyalurkan informasi dalam kegiatan belajar sehingga dapat meningkatkan komunikasi merupakan peran penting media pembelajaran (Nurdin, 2020). Media yang sangat mudah dalam membantu proses pembelajaran IPA adalah media power point. Materi IPA yang erat dengan gambar serta viode oleh sebab itu media power point merupakan pilihan tepat, siswa mampu memahami materi yang sedang dibahas dengan jelas. Oleh karena itu, kegunaan power point sebagai media menyebabkan siswa tertarik untuk mengikuti pembelajaran sehingga siswa paham terhadap materi yang diajarkan dikarenakan lebih mudah serta mampu meningkatkan hasil belajar IPA siswa itu sendiri. Fitur yang terdapat pada power point yakni menambahkan gambar, suara, video, serta animasi sehingga gambar presentasi menjadi hidup, lebih mudah diakses dan praktis dikarenakan media power point tidak perlu terkoneksi internet ketika akan menggunakannya dan ukuran file yang kecil sehingga meyebabkan tidak memerlukan ruang penyimpanan yang besar (Astawa \& Tegeh, 2020; Purwanti, Widianingrum, \& Melinda, 2018; Saputra \& Zinnurrain, 2018; Purawanti, 2020).

Kendala-kendala yang terjadi pada saat pelaksanaan pembelajaran IPA dipaparkan sebagai berikut, guru masih mendominasi proses pembelajaran, guru jarang melibatkan siswa secara langsung, siswa menjadi penerima informasi, dan guru belum mengajak siswa untuk belajar memecahkan masalah IPA. Kegiatan pembelajaran IPA yang terfokus pada materi yang disampaikan oleh guru menyebabkan siswa kurang antusias dalam pembelajaran IPA. Pembelajaran IPA seperti, mengakibatkan siswa kurang konsentrasi dalam menyimak penjelasan guru dan siswa kesulitan dalam menemukan pada materi yang disampaikan, hal ini dikarenakan pembelajaran tidak menggunakan media pembelajaran (Astuti et al., 2020; Wahyuni et al., 2020; Oktafiani et al., 2020). Selanjutnya diadakan pengamatan kegiatan pembelajaran IPA yang dilaksanakan di SD Negeri 4 Banyuasri, kegiatan pembelajaran pada di masa pandemi ini masih terdapat beberapa kendala; kurangnya penggunaan media pembelajaran yang dapat membantu siswa dalam menerima materi pembelajaran, pelaksanaan kegiatan pembelajaran IPA kurang menggunakan model pembelajaran yang inovatif, kegiatan pembelajaran hanya sebatas mengirimkan materi pembelajaran dan tugas sehingga ketertarikan siswa terhadap muatan pelajaran IPA masih kurang, dan siswa kesulitan memecahkan masalah yang berkaitan muatan pelajaran IPA yang terjadi di kehidupan sehari-hari serta terdapat nilai hasil belajar siswa yang diperoleh dari Penilaian Akhir Semester (PAS) di bawah KKM pada muatan pelajaran IPA. Kriteria ketuntasan minimal pada muatan pelajaran IPA adalah 63. Jumlah siswa kelas V di SD Negeri 4 Banyuasiri adalah 27 orang, dari jumlah tersebut terdapat 12 orang siswa yang mendapatkan nilai diatas KKM, sedangkan 15 orang siswa mendapatkan nilai dibawah KKM.

Kendala pembelajaran IPA yang telah disampaikan tersebut tentunya tidak boleh didiamkan dan segera diperbaikan dengan solusi menerapkan model discovery learning, model discovery learning adalah salah satu model pembelajaran penemuan, siswa akan dibimbing untuk mencari dan menemukan sendiri materi atau jawaban yang sedang dipelajari. Adapun tahapan model discovery learning; observasi untuk menemukan masalah, merumuskan masalah, mengajukan hipotesis, merencanakan pemecahan masalah melalui percobaan atau cara lain, melaksanakan pengamatan dan pengumpulan data, analisis data, dan menarik kesimpulan atas percobaan yang telah dilakukan atau penemuan. Pembelajaran dengan model discovery learning memiliki enam sintaks yakni: kegiatan pertama pemberian stimulus, kegiatan ke dua mengidentifikasi masalah, kegiatan ke tiga mengumpulkan data, kegiatan ke empat mengolah data, kegiatan ke lima memverifikasi, dan yang terakhir membuat kesimpulan (Ambarawati \& Ardana, 2020; Tumurun et al., 2016; In'am dan Hajar, 2017). Penelitian terdahulu menyatakan bahwa model discovery learning berbantuan media power point cocok digunakan dalam proses kegiatan pembelajaran yang dilaksanakan di kelas (Kusrini, 2018). Menyadari adanya kondisi siswa, guru, dan proses pembelajaran IPA di kelas V SD Negeri 4 Banyuasri, maka perlu diadakan Penelitian Tindakan Kelas (PTK) dengan menerapkan model discovery learning berbantuan media power point dengan tujuan meningkatkan hasil 
belajar IPA siswa kelas V sekolah dasar melalui penerapan model discovery learning berbatuan media power point

\section{METODE}

Penelitian yang dilaksanakan merupakan jenis penelitian tindakan kelas. PTK merupakan proses untuk meningkatkan mutu pembelajaran, memberikan perubahan dan dalam proses PTK melibatkan pendidik dalam kerja bersama untuk meningkatkan praktik mereka sendiri (Alimuddin, Muchsin, \& Kamaruddin, 2018). PTK bercirikan kolaboratif dan mendorong pendidik berdiskusi memperkuat hubungan dengan siswa dengan melaksanakan identifikasi terhadap permasalahan di kelas sekaligus memberi solusi dan melaksanakan pemecahan masalah (Ni'mah, 2017). Tahapan pertama: perencanaan (planning), tahapan ke dua: tindakan (action), tahap ke tiga: pengamatan (observation), dan tahap terakhir refleksi (reflection) (Bhoga, 2016). Subjek penelitian ini adalah siswa kelas V SD Negeri 4 Banyuasri yang berjumlah 27 orang terdiri dari 13 orang siswa laki-laki dan 14 orang siswa perempuan. Objek dari penelitian ini adalah hasil belajar siswa diterapkan model discovery learning berbantuan media power point. Metode pengumpulan data dalam penelitian ini yaitu metode tes. Data yang dikumpulkan dalam penelitian ini adalah data hasil belajar IPA siswa pada aspek kognitif berupa hasil belajar IPA kelas V yang diperoleh dengan memberikan tes pilihan ganda sebanyak 15 soal setelah diberlakukannya model pembelajaran discovery learning berbantuan media power point. Adapun kisi-kisi dari tes pilihan ganda siklus I dan II ditunjukkan tabel 1.

Tabel 1. Kisi-kisi Pilihan Ganda Siklus I dan II

\begin{tabular}{|c|c|c|c|c|c|}
\hline \multicolumn{2}{|c|}{ Kompetensi Dasar } & \multicolumn{2}{|r|}{ Indikator Soal } & \multirow{2}{*}{$\begin{array}{c}\begin{array}{c}\text { Level } \\
\text { Kognitif }\end{array} \\
\text { C4 }\end{array}$} & \multirow{2}{*}{$\begin{array}{c}\text { Ket. } \\
\text { Siklus I }\end{array}$} \\
\hline \multirow[t]{12}{*}{3.7} & $\begin{array}{l}\text { Menganalisis } \\
\text { pengaruh }\end{array}$ & 3.7 .1 & $\begin{array}{l}\text { Menemukan sifat-sifat benda padat, cair, dan } \\
\text { gas }\end{array}$ & & \\
\hline & $\begin{array}{l}\text { kalor terhadap } \\
\text { perubahan }\end{array}$ & 3.7 .2 & $\begin{array}{l}\text { Membandingkan sifat wujud benda (padat, } \\
\text { cair, dan gas) }\end{array}$ & C5 & Siklus I \\
\hline & $\begin{array}{lr}\text { suhu dan } \\
\text { wujud benda }\end{array}$ & 3.7 .3 & $\begin{array}{l}\text { Menganalisis perubahan wujud benda padat, } \\
\text { cair, dan gas }\end{array}$ & $\mathrm{C} 4$ & Siklus I \\
\hline & $\begin{array}{l}\text { dalam } \\
\text { kehidupan } \\
\text { sehari-hari }\end{array}$ & 3.7 .4 & $\begin{array}{l}\text { Membandingkan perubahan wujud benda } \\
\text { membeku, mencair, dan menguap dalam } \\
\text { kehidupan sehari-hari }\end{array}$ & C5 & Siklus I \\
\hline & & 3.7 .5 & $\begin{array}{l}\text { Menemukan perubahan wujud benda dalam } \\
\text { kehidupan sehari-hari }\end{array}$ & $\mathrm{C} 4$ & Siklus I \\
\hline & & 3.7 .6 & $\begin{array}{l}\text { Menganalisis perubahan wujud benda } \\
\text { mengembun, menyublim, dan mengkristal. }\end{array}$ & $\mathrm{C} 4$ & Siklus I \\
\hline & & 3.7 .7 & $\begin{array}{l}\text { Menganalisis pengaruh kalor terhadap suhu } \\
\text { suatu benda }\end{array}$ & $\mathrm{C} 4$ & Siklus II \\
\hline & & 3.7 .8 & $\begin{array}{l}\text { Menemukan peristiwa-peristiwa perubahan } \\
\text { suhu benda yang disebabkan kalor dalam } \\
\text { kehidupan sehari-hari }\end{array}$ & $\mathrm{C} 4$ & Siklus II \\
\hline & & 3.7 .9 & $\begin{array}{l}\text { Menganalisis pengaruh kalor terhadap } \\
\text { perubahan wujud benda }\end{array}$ & $\mathrm{C} 4$ & Siklus II \\
\hline & & 3.7 .10 & $\begin{array}{l}\text { Menghubungkan berbagai peristiwa } \\
\text { perubahan wujud benda akibat kalor dalam } \\
\text { kehidupan sehari-hari }\end{array}$ & C6 & Siklus II \\
\hline & & 3.7.11 & $\begin{array}{l}\text { Menganalisis perubahan wujud benda pada } \\
\text { peristiwa menguap }\end{array}$ & $\mathrm{C} 4$ & Siklus II \\
\hline & & 3.7 .12 & $\begin{array}{l}\text { Menyimpulkan perubahan wujud benda pada } \\
\text { peristiwa menguap }\end{array}$ & C5 & Siklus II \\
\hline
\end{tabular}

Setelah hasil belajar siswa diperoleh melalui metode tes pilihan ganda, hasil belajar siswa kemudian dianalisis dengan teknik analisis kuantitatif, analisis kuantitatif adalah untuk dapat mengukur dan menjabarkan hasil penelitain (Hardani, 2020). Teknik analisis deskriptif kuantitatif dalam penelitian ini dengan mencari rata-rata nilai siswa dan ketuntasan belajar siswa. 


\section{HASIL DAN PEMBAHASAN}

Hasil

Hasil belajar IPA pra siklus pada penilaian akhir semester ganjil menunjukkan hasil yang disajikan dalam bentuk tabel 2. Hasil belajar pra siklus menunjukkan, bahwa nilai rata-rata yang diperoleh siswa kelas $\mathrm{V}$ pada muatan pelajaran IPA adalah 61,66 dan persentase daya serap siswa mencapai 61,66\%. Nilai KKM digunakan sebagai acuan untuk menentukan ketuntasan belajar pada hasil belajar IPA pada kelas V di SD Negeri 4 Banyuasri. KKM yang ditetapkan untuk pelajaran IPA pada pembelajaran tematik adalah 63. Jika dilihat dari data perolehan hasil PAS (Penilaian Akhir Semester) IPA dapat diketahui bahwa dari 27 orang siswa, hanya 12 orang yang tuntas dan mencapai KKM, ketuntasan belajar (KB) siswa adalah 44,44\%. Setelah hasil belajar siswa dibandingkan ke dalam PAP skala lima tingkat hasil belajar siswa pada pra siklus berada pada kategori rendah dan terdapat permasalahan pada hasil belajar IPA siswa kelas V di SD Negeri 4 Banyuasri. Berdasarkan temuan tersebut pemecahan masalahnya diadakannya penelitian dengan menerapkan model discovery learning berbantuan media power point untuk meningkatkan hasil belajar IPA siswa kelas V di SD Negeri 4 Banyuasri.

Tabel 2. Hasil Belajar IPA pada Pra Siklus

\begin{tabular}{cc}
\hline Aspek & Pra Siklus \\
\hline Jumlah Seluruh Siswa & 27 \\
Nilai Rata-rata & 61.66 \\
Nilai Tertinggi & 80 \\
Nilai Terendah & 40 \\
Jumlah Siswa Tuntas & 12 \\
Jumlah Siswa Tidak Tuntas & 15 \\
Daya Serap & $61,66 \%$ \\
Presentase Ketuntasan Belajar & $44.44 \%$ \\
\hline
\end{tabular}

\section{Hasil Belajar IPA Siswa Siklus I}

Dilaksanakan perbaikan pembelajaran dengan model discovery learning berbantuan media power point untuk meningkatkan hasil belajar IPA siswa kelas V SD pada siklus I diperoleh hasil belajar ditunjukan pada tabel 3. diperoleh hasil belajar IPA Siklus I sebagai berikut, mean 69,94, median 71,58, modus 74,1, jumlah siswa yang tuntas 17, jumlah siswa tidak tuntas 10, daya serap 69,94\%, dan presentase ketuntasan belajar 62,96\% serta setelah dibandingkan ke skala (PAP) hasil belajar IPA siswa pada siklus I pada kategori cukup dengan hasil demikian adapun beberapa kendala yang muncul selama proses pembelajaran pada siklus I yaitu; pembelajaran secara daring belum berjalan secara optimal karena keterbatasan jaringan, fasilitas belajar, dan siswa kurang terbiasa untuk mengksplorasi berbagai informasi yang tersedia baik secara online maupun offline melalui fitur yang terdapat google form, whatsapp, dan google meet sehingga kurang optimal dalam berinteraksi dan memperoleh informasi. Kelebihan-kelebihan yang ditemukan pada pelaksanaan tindakan siklus I yaitu; menerapkan model discovery learning berbantuan media power point mendorong kemampuan siswa untuk melakukan penemuan-penemuan dalam memperoleh pengalaman belajarnya secara mandiri.

Tabel 3. Hasil Belajar IPA Siklus I

\begin{tabular}{cc}
\hline Aspek & Siklus I \\
\hline Mean & 69,94 \\
Median & 71,58 \\
Modus & 74,1 \\
Jumlah Siswa Tuntas & 17 \\
Jumlah Siswa Tidak Tuntas & 10 \\
Daya Serap & $69,94 \%$ \\
Persentase Ketuntasan Belajar & $62,96 \%$ \\
\hline
\end{tabular}

Berdasarkan pada kendala dan kelebihan tersebut perlu diberikan penguatan positif, reward, dan pengalaman belajar yang menyenangkan dengan melakukan penemuan-penemuan melalui berbagai aktivitas belajar secara daring. Guru juga memberikan bahan ajar, LKPD, dan soal evaluasi melalui whatsapp group dengam memperhatikan langkah-langkah perencanaan pembelajran yang telah disusun dan siswa diperbolehkan datang langsung ke sekolah untuk mengambil LKPD, bahan ajar, dan evaluasi sehingga siswa dapat mengikuti pembelajaran dengan baik. Selain itu, perlu adanya perbaikan yang 
mengarah pada peningkatan hasil belajar IPA siswa melalui penerapan model discovery learning berbantuan media power point yang dikembangkan peneliti pada siklus II.

\section{Hasil Belajar IPA Siswa Siklus II}

Pada hasil belajar IPA pada siklus II dengan penerapan model discovery learning berbantuan media power point diperoleh hasil belajar ditunjukkan paa tabel 5. Berdasarkan hasil belajar IPA siswa pada tabel 5 , diperoleh yakni; mean 79,85 , median 81,79 , modus 84,7 , jumlah siswa yang tuntas 22 , jumlah siswa yang tidak tuntas 5 dan setelah hasil belajar siswa dibandingkan ke dalam PAP skala lima, maka tingkat hasil belajar siswa pada siklus II berada pada kategori tinggi, ketuntasan belajar yang diperoleh adalah 81,48\%, sedangkan ketuntasan belajar yang ditetapkan adalah 80\%. Perolehan persentase daya serap pada penelitian siklus II ini adalah 78,85\%, sedangkan ketentuan yang ditetapkan adalah 70\%. Mengacu dari hasil tersebut, maka penelitian akan dihentikan sampai siklus II. Hasil penelitian peningkatan hasil belajar IPA siswa kelas V SD Negeri 4 Banyuasri pada kegiatan pra siklus, siklus I, dan siklus II yang telah dilaksanakan diperoleh hasil peningkatan penelitian pada kegiatan pra siklus, siklus I, dan siklus II yang disajikan pada gambar 1.

Tabel 5. Hasil Belajar IPA Siswa Siklus II

\begin{tabular}{cc}
\hline Aspek & Siklus II \\
\hline Mean & 79,85 \\
Median & 81,76 \\
Modus & 84,7 \\
Jumlah Siswa Tuntas & 22 \\
Jumlah Siswa Tidak Tuntas & 5 \\
Daya Serap & $79,85 \%$ \\
Persentase Ketuntasan Belajar & $81,48 \%$ \\
\hline
\end{tabular}

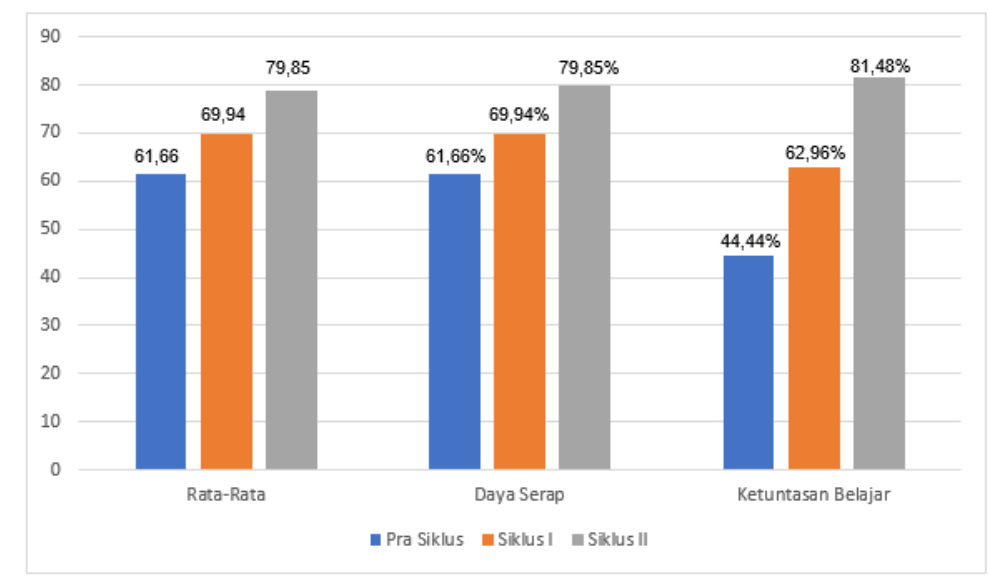

Gambar 1. Grafik Data Peningkatan Hasil Belajar IPA dari Pra Siklus, Siklus I, dan Siklus II

Berdasarkan gambar grafik 1, dapat dilihat bahwa rata-rata nilai siswa pada pra siklus mencapai 61,66 dan ketuntasan belajar siswa adalah 44,44\%, jika dikategorikan pada PAP skala lima hasil tersebut berada pada kategori rendah sehingga diperlukan perbaikan yang dapat dilakukan tindakan pada siklus I. Setelah menerapkan model discovery learning berbantuan media power point pada siklus I perolehan ratarata hasil belajar siswa adalah 69,94 dan ketuntasan belajar siswa sebesar 62,96\%, jika dikategorikan pada PAP skala lima hasil tersebeut berada pada kategori cukup. Peningkatan hasil belajar pada kegiatan pra siklus menuju siklus I terlihat cukup signifikan dengan perolehan peningkatan pada nilai rata-rata siswa sebesar 8,28 dan ketuntasan belajar sebesar 18,52\%. Selanjutnya, setelah dilaksanakannya refleksi maka penelitian dilanjutkan pada siklus II karena perolehan hasil belajar siswa belum maksimal dapat diatasi. Penelitian siklus II dilanjutkan dengan menerapkan model discovery learning berbantuan media power point. Rata-rata hasil belajar siswa adalah 79,85 dan ketuntasan belajar siswa sebesar 81,48\%, jika dikategorikan pada PAP skala lima hasil tersebeut berada pada kategori tinggi. Peningkatan hasil belajar siswa dari siklus I menuju siklus II terlihat signifikan karena perolehan peningkatan rata-rata nilai siswa sebesar 9,91 dan ketuntasan belajar sebesar 18,52\%. Merujuk pada hasil rata-rata nilai dan ketuntasan belajar siswa di siklus II sudah mencapai ketentuan yang telah ditetapkan pada indikator keberhasilan 
yaitu nilai rata-rata mencapai target minimal 70 dan ketuntasan belajar sudah mencapai target minimal 80\%. Dengan demikian, penelitian ini dihentikan sampai pada siklus II.

Peningkatan hasil belajar IPA dengan diterapkan model discovery learning berbantuan media power point pada penelitian tindakan kelas ini terjadi karena dalam langkah-langkah dalam kegiatan pembelajaran menggunakan model discovery learning terdapat tujuh kegiatan yang sesuai dengan kegiatan pembelajaran IPA memberikan pengalaman belajar langsung pada siswa melalui sikap ilmiah dengan: pemberian stimulus, identifikasi masalah, pengumpulan data, pengolahan data, pembuktian, menarik kesimpulan. Setiap kegiatan yang dialami oleh siswa, siswa dapat berfikir kritis, kreatif, serta mencoba memecahkan masalah untuk mendapatkan pengalamannya sendiri yang memberikan manfaat guna membangun pengetahuan secara mandiri sehingga selanjutnya berguna pada kehidupan bermasyarakat. Penelitian tindakan kelas ini didukung dengan teori sebagai berikut, model discovery learning berdasarkan teori konstruktivisme adalah pengetahuan yang diperoleh bertahan lama dan mudah untuk diingat karena hasil belajar melalui penemuan berdampak pada transfer of knowledge karena memperlibatkan peserta didik terhadap penemuan, menalar dan kemampuan berpikir kritis (Alimuddin et al., 2018).

Discovery learning dalam penerapannya guru memiliki peran sebagai pembimbing memberikan kesempatan pada siswa belajar secara aktif dan sesuai dengan tujuan. Kondisi seperti ini ingin mengubah kegiatan belajar siswa teacher orinted (berorientasi pada guru) menjadi student oriented (berorientasi pada siswa). Menerapkan model discovery learning dalam pembelajaran dapat: membantu siswa untuk memperbaiki dan meningkatkan keterampilan-keterampilan dan proses-proses kognitif, model ini memungkinkan siswa berkembang dengan cepat dan sesuai dengan kecepatannya sendiri, meningkatkan tingkat penghargaan pada siswa, karena unsur berdiskusi, mampu menimbulkan perasaan senang dan bahagia karena siswa berhasil melakukan penelitian, dan membantu siswa menghilangkan skeptisme (keragu-raguan) karena mengarah pada kebenaran yang final dan tertentu atau pasti. Model pembelajaran discovery leraning cocok dilaksanakan untuk pembelajaran disekolah dasar (Anggrayanthi et al., 2016; Nabila, 2019; Lubis et al., 2019). Selain itu, dengan adanya media power point pembelajaran IPA dapat menggunakan teknologi sebagai penunjang, mempermudah proses pembelajaran. Membantu siswa belajar dengan terorganisir pelajaran, penekanan pada poin-poin kunci, menjaga perhatian, memasukkan poin-poin dan ilustrasi membantu siswa memperoleh dan memahami pelajaran (Hadiyanti \& Widya, 2018). Layak digunakan dalam proses pembelajaran, salah satunya adalah memancing ketertarikan siswa dalam belajar yakni kegunaan media power point (Wijayanti \& Relmasira, 2019). Tidak memerlukan keahlian mengkhusus pendidik dan peserta didik dalam membuat dan mengoperasikan power point (Sakiah \& Effendi, 2021).

Hasil penelitian ini sesuai dengan penelitian yang telah berlangsung terdahulu yakni, hasil penelitian menunjukkan bahwa model discovery learning dapat meningkatkan hasil belajar IPA sekolah dasar (Ma'ruf, Kristin, dan Anugraheni, 2019). Dengan menggunakan model discovery learning dapat meningkatkan kreativitas dan hasil belajar IPA (Kanna, Kristin, dan Anugraheni, 2018). Penerapan media slide power point dapat meningkatkan kualitas proses pembelajaran (Fuad dan Permatasari, 2019). Berdasarkan uraian tersebut, penelitian ini dapat menjawab rumusan masalah serta dapat menentukan kebenaran dari hipotesis yang telah ditentukan. Hal ini berarti penerapan model discovery learning berbantuan media power point untuk meningkatkan hasil belajar IPA siswa kelas V dikatakan berhasil karena semua kriteria indikator keberhasilan yang telah ditentukan telah berhasil dicapai. Jadi, dapat dinyatakan bahwa penerapan model discovery learning berbantuan media power point dapat meningkatkan hasil belajar IPA siswa kelas V SD Negeri 4 Banyuasri tahun ajaran 2020/2021.

Perbedaan penelitian tindakan kelas yang lebih dahulu berlangsung dan yang terjadi saat ini adalah terletak pada subjek penelitian yang terdahulu pada siswa kelas IV sekolah dasar dan untuk meningkatkan kreativitas siswa tanpa berbantuan media power point. Adapun kelebihan dari penelitian tindakan kelas model discovery learning berbantuan media power point adalah dengan model discovery learning pembelajaran IPA dilaksanakan dengan beragam penemuan dan lebih kontekstual dan melalui menggunakan media pembelajaran power point dapat melatih kemandirian belajar siswa di rumah. Implikasi dari adanya penelitian tindakan kelas ini adalah guru dan siswa dapat menggunakan informasi dan teknologi berupa penggunaan media power point sebagai media yang mempermudah kegiatan pembelajaran IPA dan dapat memperoleh dampak positif dari adanya penggunaan teknologi, selain impilkasi adapun kendala-kendala dalam penelitian tindakan kelas melalui model discovery learning berbantuan media power point adalah saat pengiriman materi melalui media power point hal ini karena terkendala jaringan, kontribusi untuk penelitian selanjutnya dapat menggunakan media power point dengan mengirimkan materi dalam bentuk file di flash disk dan melaksanakan penelitian sejenis pada pembelajaran lainnya dengan menggunakan media pembelajaran yang berbeda. 


\section{SIMPULAN}

Berdasarkan hasil penelitian dan pembahasan menyatakan bahwa Model discovery learning berbantuan media power point dapat meningkatkan hasil belajar IPA siswa sekolah dasar. Berdasarkan terjadinya peningkatan hasil belajar IPA, saran untuk penelitian selanjutnya adalah dapat menerapkan model discovery learning pada mata pelajaran lainnya dan menggunakan media pembelajaran yang berbeda.

\section{DAFTAR PUSTAKA}

Abhyasari, N. P., Kusmariyatni, N. N., \& Agustiana, I. G. A. T. (2020). Pengaruh Pembelajaran Berpendekatan Saintifik Berbasis Masalah Terhadap Disiplin dan Hasil Belajar IPA. Mimbar PGSD Undiksha, 8(1), 111-122. http://dx.doi.org/10.23887/jjpgsd.v8i1.24547.

Adnyana, I. G. A. D., Margunayasa, I. G., \& Kusmariyatni, N. (2019). Pengaruh Model Pembelajaran Word Square Berbantuan Media Gambar Terhadap Keterampilan Berbicara. Jurnal Ilmiah Sekolah Dasar, 3(3), 174. https://doi.org/10.23887/jppp.v3i3.18160.

Alimuddin, H., Muchsin, S. B., \& Kamaruddin, R. (2018). Pentingnya PTK Bagi Guru. Matappa, 1(2), 101106. https://doi.org/DOI:10.31100/matappa.v1i2.231.

Ambarawati, N. L. M., \& Ardana, I. K. (2020). Efektivitas Model Pembelajaran (CIRC) Berbantuan Scramble Terhadap Kompetensi Pengetahuan IPA. Mimbar Pgsd, Volume 8(1), 61-69. http://dx.doi.org/10.23887/jjpgsd.v8i1.24579.

Anggrayanthi, L. A., Suniasih, N. W., \& Suara, I. M. (2016). Penerapan Model Discovery Learning Berbantuan Media Lingkungan Untuk Meningkatkan Hasil Belajar IPA Tema Ekosistem Siswa Kelas VA SD N 12 Padang Sambian. Mimbar PGSD, 4(1), 1-10. http://dx.doi.org/10.23887/jjpgsd.v4i1.7461.

Astawa, P. A., \& Tegeh, I. M. (2020). Pengaruh Model Pembelajaran Kooperatif Tipe Make a Match Terhadap Hasil Belajar Matematika. Ilmiah Sekolah Dasar, 10(3), 223. https://doi.org/10.26858/publikan.v10i3.15159.

Astuti, A. A. I. Y., Wibawa, I. M. C., \& Suarjana, I. M. (2020). The Effectiveness of Problem Based Learning Toward Students' Science Learning Outcomes. Jurnal Ilmiah Sekolah Dasar, 4(4), 573-580. https://ejournal.undiksha.ac.id/index.php/JISD/article/view/25667.

Bhoga, V. U. (2016). Kajian Pelaksanaan Penelitian Tindakan Kelas Oleh Guru-Guru Sd Di Kecamatan $\begin{array}{llll}\text { Jerebuu. Jurnal Ilmiah Pendidikan, } & \text { 4(1), }\end{array}$ https://www.researchgate.net/publication/339126014_Pentingnya_PTK_Bagi_Guru.

Dewi, A. T. Y. R., \& Negara, I. G. A. O. (2020). Pengaruh Model Pembelajaran ( SAVI ) Berbantuan Multimedia Terhadap Kompetensi Pengetahuan IPA. Mimbar PGSD, 8(1), 40-49. http://dx.doi.org/10.23887/jjpgsd.v8i1.24577.

Dewi, N. S., Astawa, I. G., \& Margunayasa, I. G. (2020). Meta-Analisis Pengaruh Model Problem Based Learning Terhadap Hasil Belajar IPA Siswa Sekolah Dasar. Mimbar PGSD, Volume 3(3), 416-427. http://dx.doi.org/10.23887/jjpgsd.v8i2.25458.

Fuad, A. J., \& Permatasari, A. D. (2019). Penggunaan Media Slide Powerpoint dalam Meningkatkan Prestasi Belajar Siswa Sekolah Dasar Pada Pembelajaran Tematik. EL Bidayah: Journal of Islamic Elementary Education, 1(1), 61-78. https://doi.org/10.33367/jiee.v1i1.683.

Hadiyanti, W., \& Widya. (2018). Analyzing The Values And Effects Of Power Point Presentations. LLT, 21(1), 87-95. https://doi.org/10.24071/llt.v21iSuppl.935.g985.

Hardani. (2020). Metode Penelitian Kuantitatif dan Kualitatif. Pustaka Ilmu.

Hikmawati, F. (2017). Metodologi Penelitian. Raja Grafindo.

In'am, A., \& Hajar, S. (2017). Learning Geometry through Discovery Learning Using a Scientific Approach. International Journal of Instruction, 10(1), 55-70. http://www.e-iji.net/dosyalar/iji_2017_1_4.pd.

Kanna, R., Kristin, F., \& Anugraheni, I. (2018). Penerapan Model Pembelajaran Discovery Learning Untuk Meningkatkan Kreativitas Dan Hasil Belajar Pada Mata Pelajaran Ipa Kelas 5 SD. Kalam Cendekia, 6(4), 1-8. http://jurnal.fkip.uns.ac.id/index.php/pgsdkebumen/article/view/11960/8532.

Kusrini. (2018). Efektivitas Model Pembelajaran Discovery Learning Berbantuan Media Powerpoint Untuk Meningkatkan Hasil Belajar Siswa. Musamus Journal of Science Education, 1(1), 027-032. https://doi.org/10.35724/mjose.v1i1.943.

Lubis, A. B., Miaz, Y., \& Putri, I. E. (2019). Influence of the Guided Discovery Learning Model on Primary School Students' Mathematical Problem-solving Skills. Mimbar Sekolah Dasar, 6(2), 253. https://doi.org/10.17509/mimbar-sd.v6i2.17984.

Ma'ruf, M. I., Kristin, F., \& Anugraheni, I. (2019). Penerapan Model Pembelajaran Discovery Learning Untuk Meningkatkan Keaktivan dan Hasil Belajar Siswa Kelas 4 SD. Basicedu, 3(2), 1. 
https://doi.org/10.31004/basicedu.v3i2.7.

Nabila. (2019). Penggunaan Model Pembelajaran Discovery Learning Dalam Peningkatan Hasil Belajaran Siswa Di Sekolah Dasar. Ilmiah Pendidikan Dan Pembelajaran, 18(2), 56. https://doi.org/10.24036/fip.100.v18i2.318.000-000.

Ni'mah, Z. A. (2017). Urgensi Penelitian Tindakan Kelas Bagi Peningkatan Profesionalitas Guru: Antara Cita dan Fakta. Realita, 15(2), 1-11. https://jurnal.iainkediri.ac.id/index.php/realita/article/view/480/309.

Nurdin, M. (2020). Artikel Media Pembelajaran Audiovisual berbasis Internet Artikel Media Pembelajaran Audio Visual. Media Pembelajaran, 1(May), 2. https://www.neliti.com/publications/271164.

Nurrita, T. (2018). Pengembangan Media Pembelajaran Untuk Meningkatkan Hasil Belajar Siswa. MISYKAT: Jurnal Ilmu-Ilmu Al-Quran, Hadist, Syari'ah Dan Tarbiyah, 3(1), 171. https://doi.org/10.33511/misykat.v3n1.171.

Oktafiani, D., Nulhakim, L., \& Alamsyah, T. P. (2020). Pengembangan media pembelajaran IPA berbasis multimedia interaktif menggunakan Adobe Flash pada Kelas IV. Mimbar PGSD Undiksha, 8(3), 527-540. http://dx.doi.org/10.23887/jjpgsd.v8i3.29261.

Phalguna, I. W. W., \& Putra, D. K. S. (2020). Talking Stick Learning Model Assisted with Audiovisual Media Toward Science Knowledge Competence. Ilmiah Sekolah Dasar, 4(4), 563-572. http://dx.doi.org/10.23887/jisd.v4i4.25515.

Purawanti, D. (2020). Peningkatan Keterampilan Menyimak Melalui Media Audio Visual Siswa Kelas VIII A SMP N 2 Bahorok Kabupaten Langkat. JPPP, 1(1), 113-121. http://jurnal.umsu.ac.id/index.php.

Purwanti, L., Widyaningrum, R., \& Melinda, S. A. (2018). Analisis Penggunaan Media Power Point dalam Pembelajaran Jarak Jauh pada Materi Animalia Kelas VIII. Journal of Biology Education, 3(2), 157. https://doi.org/10.21043/jobe.v3i2.8446.

Rianti, E., \& Dibia, I. K. (2020). Pendekatan PAIKEM Berbantuan Brain Gym Berpengaruh terhadap Konsentrasi Belajar IPA. MIMBAR PGSD Undiksha, 8(2), 225-237. http://dx.doi.org/10.23887/jjpgsd.v8i2.26479.

Sakiah, N. A., \& Effendi, K. N. S. (2021). Analisis Kebutuhan Multimedia Interaktif Berbasis PowerPoint Materi Aljabar Pada Pembelajaran Matematika SMP. JP3M (Jurnal Penelitian Pendidikan Dan Pengajaran Matematika), 7(1), 39-48. https://doi.org/10.37058/jp3m.v7i1.2623.

Saputra, H. G., \& Zinnurrain. (2018). Pengaruh Penggunaan Meida MS Power Point Berbasis Game Terhadap Hasil Belajar Siswa. Jurnal Teknologi Pendidikan, 3(1), 11-19. http://www.jurnalpedagogika.org.

Tumurun, S. W., Gusrayani, D., \& Jayadinata, A. K. (2016). Pengaruh Model Pembelajaran Discovery Learning Terhadap Keterampilan Berpikir Kreatif Siswa Pada Materi Sifat-Sifat Cahaya. Jurnal Pena Ilmiah, 1(1), 101-110. https://doi.org/10.23819/pi.v1i1.2936.

Wahyuni, L. T. S., Japa, I. G. N., \& Rati, N. W. (2020). Correlation of Reading Interests and Learning Motivation Toward Science Learning Outcomes. Jurnal Ilmiah Sekolah Dasar, 4(3), 484. https://doi.org/10.23887/jisd.v4i3.25376.

Wijayanti, W., \& Relmasira, S. C. (2019). Pengembangan Media PowerPoint IPA Untuk Siswa Kelas IV SD Negeri Samirono. Jurnal Penelitian Dan Pengembangan Pendidikan, 3(2), 77. https://doi.org/10.23887/jppp.v3i2.17381. 